\title{
Wild cassava, Manihot spp.: Biology and potentialities for genetic improvement*
}

\author{
Nagib M.A. Nassar
}

\begin{abstract}
Wild species of Manihot are progenitors of cassava. They constitute valuable genetic reservoirs presenting genes that show new characters. Screening of these species showed some of them to have a notably high percentage of protein combined with a low percentage of hydrocyanic acid. Study of natural habitats revealed resistance to drought and excessive soil aluminum toxicity as well as adaptation to low temperature. Some of the hybrids obtained showed high root productivity and resistance to stem borers. Apomixis was discovered in the wild and transferred successfully to the cultivate species.
\end{abstract}

\section{TAXONOMICAL ASPECTS}

Cassava, Manihot esculenta Crantz, does not grow wild. However, about 98 species belonging to the genus Manihot (Rogers and Appan, 1973), ranging from subshrubs, shrubs to trees, are known. The majority of them produce latex and contain cyanogenic glucoside. Contrary to those of the cultigen, roots of wild species are fibrous and slender; some species frequently exhibit a limited number of tuberous root. Root surface is smooth or rough, and subepidermis varies from red or yellow to white. The cortex of tuberous rooted species is white, cream colored or yellow.

Stem height varies from almost acaulescent in subshrubs to about $20 \mathrm{~m}$ in tree species. Shrubs native to the Brazilian savanna frequently have their stem die back to the crown in the dry season. Stem color varies from gray or brown to reddish. Stems normally branch into dichotomas or trichotomas. The branching points exhibit a terminal inflorescence. In wild species frequently the young stem has a varying degree of pubescence, a character rarely encountered in the cultigen (Nassar and Grattapaglia, 1986).

Leaves are alternate varying from subsessile to long petiolated. All species with exception of three produce palmately lobed leaves. Inflorescence is terminal, monoeceous with the exception of the acaulescent species native to Central Brazil. Flowers have a single perianth composed of 5 petals, with length ranging from 0.5 to $2.0 \mathrm{~cm}$. Buds of staminate flowers are ovoid or spheric; those of pistillates are conic. Fruits are capsules with three locules. Seeds have caruncles varying in size. Chromosome number in all species investigated is $2 \mathrm{n}=36$ (Nassar, 1978a).

All species of the genus Manihot are native to the New World; in Brazil and Mexico they form distinct centers of diversity (Nassar, 1978b). In their habitats their growth is normally sporadic, rarely becoming dominant in the vegetation. Due to the monoeceous or dioecious structure of the inflorescence, wild Manihot species are typically alogamous plants. However, in cultivated cassava a shift towards autogamous plants has occurred. Nassar and O'Hair (1985) explained this as consequent to monoclonal system of cultivation and the domestication history. Observations of frequent hybridization between wild species and the cultigen and between the wild species themselves suggest weak barriers in the genus (Nassar, 1980a). This is probably due to the polyploid origin at the genus level.

\section{DETERMINATION OF WILD MANIHOT SPECIES LOCALITIES WITH EMPHASIS ON PROBABLE ORIGIN}

Distribution of Manihot species was studied by Nassar (1978a). Table I lists the wild species of Manihot collected from different localities in northeastern Brasil. It is apparent that western Pernambuco and central Bahia present the greatest variability in Manihot. It may be worth mentioning that certain species reported to occur in some localities could not be colleted from these places. To exemplify: specimens of M. glaziovii collected from about $12 \mathrm{~km}$ west of Ibimirim, PE, could not be found because vegetation in that location unfortunately had been cleared and the land cultivated with the castor bean plant (Recinus comunis), mamona. Unlike most Manihot species, $M$. glaziovii grows in large numbers and not as a sporadic plant. Extinction of some wild Manihot species from their rural habitats may be due to another factor, namely that the majority of theses species are poisonous to grazing animals because of the presence of HCN. They are known among people of the Brazilian Northeast as "maniçoba", i.e., the poisonous cassava. Many plants are exterminated by farmers for this reason.

By studying the geographic distribution of Manihot 
Table I - Wild species of Manihot collected from different localities in northeastern Brazil.

\begin{tabular}{|ll|}
\hline Species & Locality \\
\hline M. caerulescens Pohl & Aparipina, $\mathrm{PE}$ \\
M. heptaphylla Ule & Seabra, BA \\
M. cichotoma Ule & Jequié, BA \\
M. catingae Ule & Itaberaba, BA \\
M. brachyandra Pax et Hoffmann & Petrolina, PE \\
M. maracasensis Ule & Itambé, BA \\
M. epruinosa Pax et Hoffmann & Bentecoste, Fortaleza, CE \\
M. glaziovii Mueller & Arcoverde, Ouricure, \\
& Serratalada, PE \\
M. jacobinensis Mueller & Vitória da Conquista, BA \\
M. quinquefolia Pohl & Senhor do Bonfim, \\
& Juazeiro, BA \\
\hline
\end{tabular}

species in both Rogers and Appan (1973) in combination with localities determined on this trip, it became possible to draw a map of the regional concentration of wild Manihot species. It showed that central Brazil (southern Goiás and eastern Minas Gerais) has about 38 wild species of the total of the 98 species recognized. Thus, by including the largest number of wild Manihot species, this region presents the highest diversity.

The following species occur in this region:

M. acuminatissima Mueller

M. sparsifolia Pohl

M. pruinosa Pohl

M. alutacea Rogers et Appan

M. divergens Pohl

M. cecropiaefolia Pohl

M. triphylia Polh

M. pentaphylla Pohl

M. anomala Pohl

M. procumbens Mueller

M. crotalariaformis Pohl

M. pusilia Pohl

M. logepetiolata Pohl

M. tomentosa Pohl

M. purpureo-costata Pohl

M. attenuata Mueller

M. orbicularis Pohl'M. tripartita (Sprengel) Mueller

M. pilosa Pohl

M. sagittato-partita Pohl

M. falcata Rogers et Appan

M. quinqueloba Pohl

M. violacea Pohl

M. irwinii Rogers et Appan

M. mossamedensis Taubet

M. fruiculosa (Pax) Rogers et Appan

M. gracilis Pohl

M. warmingii Mueller

M. replans Pax

M. stipularis $\mathrm{Pax}$

M. oligantha $\mathrm{Pax}$
M. nana Mueller

M. stricta Baillon

M. salicifolia Pohl

M. weddelliana Baillon

M. peltata Pohl

M. janiphoides Mueller

M. handroana N.D. Cruz

The second center of diversity is southwestern

Mexico. It includes:

M. pringlei Watson

M. aesculifolia Pohl

M. oaxacana Rogers et Appan

$M$. rhomboidea Mueller

M. easkerae

M. waskearae Croizat

M. divisiae Croizat

M. michaelis McVaugh

M. websterae Rogers et Appan

M. aurivulata Mcvaugh

M. rubricaulis I.M. Hohnson

M. chlorosticta Standley \& Goldman

M. subspicata Rogers et Appan

$M$. caudata Greenman

M. angustiloba (Torrey) Mueller

M. tomatophylla Standley

M. foetida Pohl

The third center of diversity is northeastern Brazil, which includes:

M. zentneri Ule

M. surinamensis Rogers et Appan

M. quinquefolia Pohl

M. pseudoglaziovii Pax et Hoffmann

M. maracasensis Ule

M. quinquepartita Huber

M. caerulescens Pohl

M. marajoara Chermont de Miranda

M. tristis Mueller

M. glaziovii Mueller

M. epruinosa Paz et Hoffmann

$M$. brachyandra Pax et Hoffmann

M. dichotoma Ule

M. leptophylla Pax

M. reniformis Pohs

M. heptaphylla Ule

The fourth center of diversity is western Mato Grosso do Sul and Bolivia which includes the following species:

$M$. guaranitica Choda et Hassier

M. pruinosa Pohl

M. jacobinsis Mueller

M. condesata Rogers et Appan

M. xavantinensis Rogers et Appan

M. flemingiana Rogers et Appan

Vavilov (1951) showed that variation in cultivated plants is confined to relatively few restricted areas or centers. He set up six main geographic centers for cultivated plants, a number later (1935) increased to about ten, and 
assumed that cassava has a Brazilian-Bolivian center of diversity. He further proposed that centers of diversity are places of origin of cultivated plants. After this exposition of centers of diversity in the 1920's, much more information has been gathered, and it has become clear that not all centers of diversity represent centers of origin.

Thanks to Harlan (1961), it was shown that more than one center of diversity may be formed for a given crop through introgression. This explains why in many cases centers of diversity for a given crop are found far from areas of much diversity of wild relatives. Since Harlan proposed this theory (giving a convincing example of the evolved species of Helianthus), much evidence in its support has been provided. Dobzhansky (1973) cited many conspicuous cases, such as formation of species of Iris, Eucalyptus, Liatris, Penstemon, and Tragopogon.

Thus, this phenomenon serves as a model for what apparently happened during the formation of these four centers of diversity of Manihot. Assuming that cassava was domesticated for the first time in a single place, and then carried by immigrating Indians, this could lead to extensive hybridization between the cultivated and local wild species, giving rise to numerous new species through introgression.

Cassava does not grow wild. The large variation of cassava cultivars maintained by vegetative reproduction over hundreds of years makes it difficult to attribute definite characters to M. esculenta. It is believed that this species did not arise by natural selection. Hybrids between some wild species may have been domesticated and subsequently maintained by vegetative reproduction. Certainly, had these cultivars been left for sexual reproduction and subjected to natural selection, this would have led to different populations with specific gene pools depending mainly on local environments.

We assume that domestication included some natural hybrids and that selected plants were maintained by vegetative reproduction for hundreds of years. This assumption is supported by the fact that many observed experimental crosses led to frequent hybridity of cultivars of M. esculenta and local wild species (Lanjouw, 1939; Nichols, 1947; Bolhuis. 1953; Jennings, 1959; Maggon et al., 1966; Cruz, 1968; Abraham, 1975; Nassar, 1980a, 1986b, 1992).

It seems that in this genus, systems of genetic and cytologic barriers have not been well established. Another support may come from the Schmidt's (1951) statement that the very rapid response of selection in different wild species leads to increased starch content in tubers and tuber formation over a low number of generations. It seems that many different wild species have the potentiality to increase tuber formation and starch content. Nassar (1978a) observed two tree species of Manihot (M. epuinosa and $M$. brachyandra) frequently found in dooryards at Goiânia which presented considerable tuber production.

These two species natives of Bahia were probably carried by people of this state during immigration which was frequent during the last thirty years due to the rapid development of the State of Goiás. This assumption that domestication included hybrids and not a given wild species has been referred to by Rogers (1963), who used the expression species complexity.

A claim that cassava has arisen from a type with high morphological similarity called M. fabellifoia was presented by an author (Allem, 1994), but it seems extremely confused. In his article, the referred author defines a second type M. peruana as an ancestor also. No support come from genetics, cytogenetics, molecular biology, ethnobotany or archeology was presented by him. On the contrary, the recent molecular study of Hayson et al. (1994) showed that the so-called $M$. flabellifolia cannot be considered as a wild Manihot species. This means it is no more than escape form. This type is a progeny of the cultigen adapted to certain environmental niches. If it is left for further generations it would segregate giving rise to cassava itself. This is applied to the type M. peruana. Both types are product of $M$. esculenta itself and not ancestor to it. To confirm the ancestral nature of a putative ancestor, a cytogenetic procedure is essential. It consists in hybridizing it with cassava to see how is the pairing in the hybrid. Has this author made this to realize his theory? The place of domestication still requires considerable discussion. Nassar (1978a) preferred to use the term "place of domestication" rather than "center of origin", since it is obvious that this crop was brought to existence by means of natural selection of wild species. Studying the history of ethnological groups in Brazil and their immigrations throws light on the subject. It has been reported that the Aruak who lived in northern Amazonia more than a thousand years ago (Schmidt, 1951) knew cassava and practised a developed agriculture. Their name in the Indian language means "people who eat tubers", and it can be seen from numerous reports that they cultivated cassava many centuries prior to Columbus. The Aruak were forced to immigrate in the 11th century to Central America, crossing the Caribbean and establishing themselves for some time in the West Indies. Many reasons have been proposed to explain their immigration: escaping from enemies, or possibly looking for a place where man does not die. But the most important reason was that they were searching for a better soil to cultivate cassava. However, this immigration coincided with the formation of a center of diversity in Mexico where Cassava carried by the Aruak would expectedly hybridize with local wild species creating such a center of diversity. Continuing Aruak immigration to the Bolivian planalto and to central Brazil coincided with the existence of the two centers of diversity in these regions. The northeastern Brazilian center of diversity is believed to be the results of the immigration of the Tupi-Guarani group.

It remains to be determined which of these four centers constitutes the primary center of diversity of Manihot. In other words, Manihot as a "biological group" must have passed their differentiation in a certain region to species spread to other regions. It could seem that central Brazil 
with its enormous number of species of Manihot is the primary center. Indeed, this region is an ancient area long available for the growth of the angiosperms. Stebbins explanations (1950) of Vavilov's interpretation of diversity patterns may be useful here: it is an elaboration of Wills' Age-and-Area hypothesis, which states that the longer a given biological entity occupies an area, the greater the variability presented by Manihot species, rendering it a primary center of diversity. This assumption finds support in the fact that species which exhibit the most primitive characteres are restricted to this region: M. stipularis Pax, M. pusilla Pohl, $M$. longipetiolata Pohl with their dioecious inflorescences and M. stricta Baillon, M. purpureocostata Pohl and M. salicifolia Pohl with their nonlobed and sessile leaves.

\section{RELATIONSHIPS BETWEEN MANIHOT SPECIES}

According to Rogers and Appan (1973), 98 Manihot species have been recognized. Only one species, $M$. pauciflora, is known in the most closely related genus, Manihotoides. Several of its attributes are not found in any Manihot species, e.g., uniflorous inflorescences, a primitive character compared with the multi-flowered inflorescence in Manihot leaves born at the apex of short, condensed stems arising from branchlets. Rogers and Appan (1973) classified Manihot species into 19 sections, varying from trees in the section Glazioviannae to subshrubs, nearly acaulescent, in the section Stipularis. The species in this latter section are also characterized by being more dioecious than monoecious, a condition opposite to that found in all other Manihot species. Other sections, such as Tripartitae and Graciles, are perennial subshrubs, with large woody roots; their stems frequently die back to the root crown in response to dry periods or fires.

All Manihot species are native to tropical regions of the New World, particularly Brazil and Mexico. Nassar (1978a) has defined four centers of diversity for these especies: Mexico, and Northeastern, Central, and Southwestern Brazil.

Microcenters of diversity of these species exist within Central Brazil, where large numbers of species are concentrated in small areas of less than $50 \mathrm{~km}$ in diameter (Nassar, 1978a to 1986b). Nassar attributes the formation of these microcenters to the frequent hybridization between species and the heterogeneous topography of their habitats, which help isolate fragmented gene pools that lead to speciation.

Tree-like species, such as M. glaziovii and M. pseudoglaziovii, are found in Northeastern, while short species and subshrubs are found in Central Brazil.

Natural hybridization occurs between wild Manihot species and between the latter and cassava (Nassar, 1984 and 1989). Barriers within the genus appear to be weak due to the recent evolution of the group. All wild Manihot species examined cytogenetically have a chromosome number of $2 \mathrm{n}=36$ (Nassar, 1978b) (Table II).
Table II - Chromosome number in wild Manihot species

\begin{tabular}{|lccc|}
\hline Species & Growth habitat & $\mathrm{N}$ & $2 \mathrm{n}$ \\
\hline$M$. handroana & Shrub & - & 36 \\
$M$. jolyana & Shrub & - & 36 \\
$M$. tripartita & Shrub & - & 36 \\
$M$. tripartita & Shrub & 18 & - \\
$M$. tweedieana & Shrub & - & 36 \\
$M$. humilis & Subshrub & - & 36 \\
$M$. pedicellaris & Shrub & - & 36 \\
$M$. gracilis & Subshrub & - & 36 \\
$M$. gracilis & Subshrub & 18 & - \\
$M$. dichotoma & Tree & - & 36 \\
$M$. glaziovii & Tree & 18 & - \\
$M$. glazivoii & Tree & & 36 \\
$M$. anomala & Shrub & 18 & - \\
$M$. zehntneria & Shrub & 18 & - \\
$M$. olighanta & Subshrub & 18 & - \\
$M$. nana & Subshrub & 18 & - \\
$M$. tomentosa & Subshrub & 18 & - \\
\hline
\end{tabular}

- Not examined.

In spite of this high chromosome number, Manihot species behave meiotically as diploids, so they are believed to be allopolyploidized. This seems to have preceded the emergence of the group as a whole and to have being responsible for their rapid speciation and their weak interspecific barriers, leading to interspecific hybridization. An extremely heterozygous gene pool is thus created, followed by differentiation; this begins a sequence of hybridization followed by speciation. Nassar (1980a) reported frequent hybridization between $M$. reptans $\mathrm{Pax}$ and $M$. alutacea Rogers and Appan, in sympatric natural habitats where population boundaries overlap. Morphological marker gene leaf color and bract size were used to identify this interspecific hybridization.

The range of $M$. reptans has expanded over the last 100 years (Nassar, 1984), a fact attributed to the continuing gene introgression of Manihot species. Introgression of $M$. reptans with germplasm from other species allowed its ecotypes to penetrate and colonize areas where $M$. reptans (pure) had been unable to do so before. This phenomenon was also noted in other species such as $M$. cearulescens (Nassar, 1980a). From a plant breeding viewpoint, the high value of these hybrids lies in their ability to cross with the cultigen.

Gene markers: lobe shape, presence of stem nodes, flower disc color, fruit color, and fruit shape were discovered in controlled crosses between cassava and wild Manihot species, as well as in natural hybrids between cassava and different species. These genes were used by Nassar to identify hybridization.

Interspecific hybrids of cassava with $M$. glaziovii, $M$. pseudoglaziovii, M. aesculifolia, M. pilosa, M. corymbilora, M. dichotoma, M. pohlii, M. neusana, M. anomala were obtained by Nassar through controlled crosses, although their frequency was low. The meiotic behavior of several hybrids 
(cassava with M. neusana; cassava with M.pseudoglaziovii) was studied by Nassar (1992), and the results indicated low hybrid fertility between these species and cassava.

\section{Relationship as seen from electrophoresis}

Grattapaglia et al. (1986) conducted a biosystematic analysis of wild Manihot species based on soluble seed protein pattern. Nineteen species were analyzed electrophoretically (Table III). A similarity matrix between species, which considered differences in band density and number, was established. Several species were found to be highly similar, for example, $M$. fruticolosa and $M$. pentaphylla, and M. pilosa and M. corymbiflora. These results correlate well with the taximetric analysis made by Rogers and Appan (1973). Manihot pilosa and M. corymbiflora are the species most similar to cassava. Profile analysis confirmed the introgression between $M$. cearulescens and cassava.

\section{Conducting electrophoresis of Manihot soluble protein}

In their electrophoretic study on Manihot species, Grattapaglia et al. (1986) conducted it according to Laemmli (1970). The concentrator gel containing $5.5 \%$ of acrylamide Tris- $\mathrm{HCl}, \mathrm{pH}=6,8$ was prepared, and fixed for $12 \mathrm{~h}$ in $5 \%$ trichloroacetic acid. Bands were stained with brilliant blue Coomassie $0.65 \%$. Every species had its profile tested in four different gels. Approximate molecular weights (AMW) were determined according to Weber and Osborn (1969).

To proceed profile analysis, 15 bands were selected as references evaluated in every one of the four profiles obtained for every species. They were classified into four categories of intensity: A: absence of color; B: low visibility; C: visible; D: intense color; E: very intense color.

For quantitative comparison of the protein pattern total values of every band were calculated and expressed in a number.

The protein profiles varied in band intensity in comparison with the 15 bands selected as references. The wild Manihot species showed variability in morphology, growth habit, and geographic distribution. This variation was reflected in the electrophoretic profiles by differences in number and intensity of visible bands.

The two varieties of cassava studied showed $78 \%$ similarity of different species of the section Glaziovinae; M. glaziovii Muell. and M. pseudoglaziovii Pax et Hoff. showed a high index of similarity based on electrophoresis analysis. A high similarity of $78 \%$ was found also in species of the section Gracilis. The same high similarity was found in species of the section Heterophyllae. Within this section, in the species M. pilosa and M. corymbiflora, the highest electrophoretic similarity to the cultivated $M$. esculenta Crantz coincided with morphological affinities between these two species and cassava. Probably they are part of the complex from which the cultigen had originated (Nassar, 1978).

The high similarity between species in certain sections shows their recent speciation and agrees with the taxonomic classification. Genetically saying, they probably share the same gene pool.

\section{GENETIC VARIATION OF WILD MANIHOT}

Wild Manihot species were collected by Nassar (1978a-d, 1980) from South and Central America, evaluated, reproduced and maintained in a living collection (Figure 1); description and identification of the wild Manihot

Table III - Wild Manihot species studied and their identification number in the germplasm bank at the Universidade de Brasília.

\begin{tabular}{|c|c|c|c|c|c|}
\hline Species & & Section & Habitat & No. & No. of Herbarium \\
\hline M. esculenta Crantz (var. EAB) & I & Manihot & Brasília (DF) & 01 & 01 \\
\hline M. esculenta Crantz (var. RB) & & Manihot & Brasília (DF) & 02 & $01 / \mathrm{a}$ \\
\hline M. zehntnieri Ule & & Heterophyllae & Goiânia (GO) & 173 & 02 \\
\hline M. grahami Hooker & II & Heterophyllae & Maringá (PR) & 375 & 03 \\
\hline M. pilosa Pohl & & Heterophyllae & São Miguel de Antes (MG) & 601 & 04 \\
\hline M. corymbioflora $\mathrm{Pax}$ & & Heterophyllae & São Miguel de Antes (MG) & 605 & 05 \\
\hline M. pohlii Wawra & & Heterophyllae & Lençóis (BA) & 139 & 06 \\
\hline M. glaziovii Muell & III & Glaziovinae & Pentocoste (CE) & 221 & 08 \\
\hline M. pseudoglaziovii Pax 7 Hoff & & Glaziovinae & Remigio (PB) & 545 & 09 \\
\hline M. epruinosa $\mathrm{Pax} \&$ Hoff. & & Glaziovinae & Serra Talhada (PE) & 554 & 10 \\
\hline M. brachyandra Pax \& Hoff. & & Glaziovinae & Currais Novos (RN) & 524 & 11 \\
\hline M. reptans $\mathrm{Pax}$ & IV & Crotalariaeformes & Corumbá (GO) & 602 & 13 \\
\hline M. alutacea Rogers \& Appan & V & Quinquelobae & Goiás Velho (GO) & 115 & 07 \\
\hline M. fruticulosa Rogers \& Appan & VI & Graciles & Alexânia (GO) & 162 & 10938 \\
\hline M. pentaphylla Pohl & & Graciles & Goiás Velho (GO) & 103 & 11755 \\
\hline M. stipularis $\mathrm{Pax}$ & VII & Stipulares & Alexânia (GO) & 184 & 14 \\
\hline M. salicifolia Pohl & VIII & Brevipetiolatae & Xavantina (MT) & 195 & - \\
\hline M. caerulescens subsp. Caerulescens & IX & Caerulescentes & Picos (PI) & 258 & 15 \\
\hline M. caerulescens (nonclassified) & & Caerulescentes & Morro do Chapéu (BA) & 567 & 16 \\
\hline
\end{tabular}




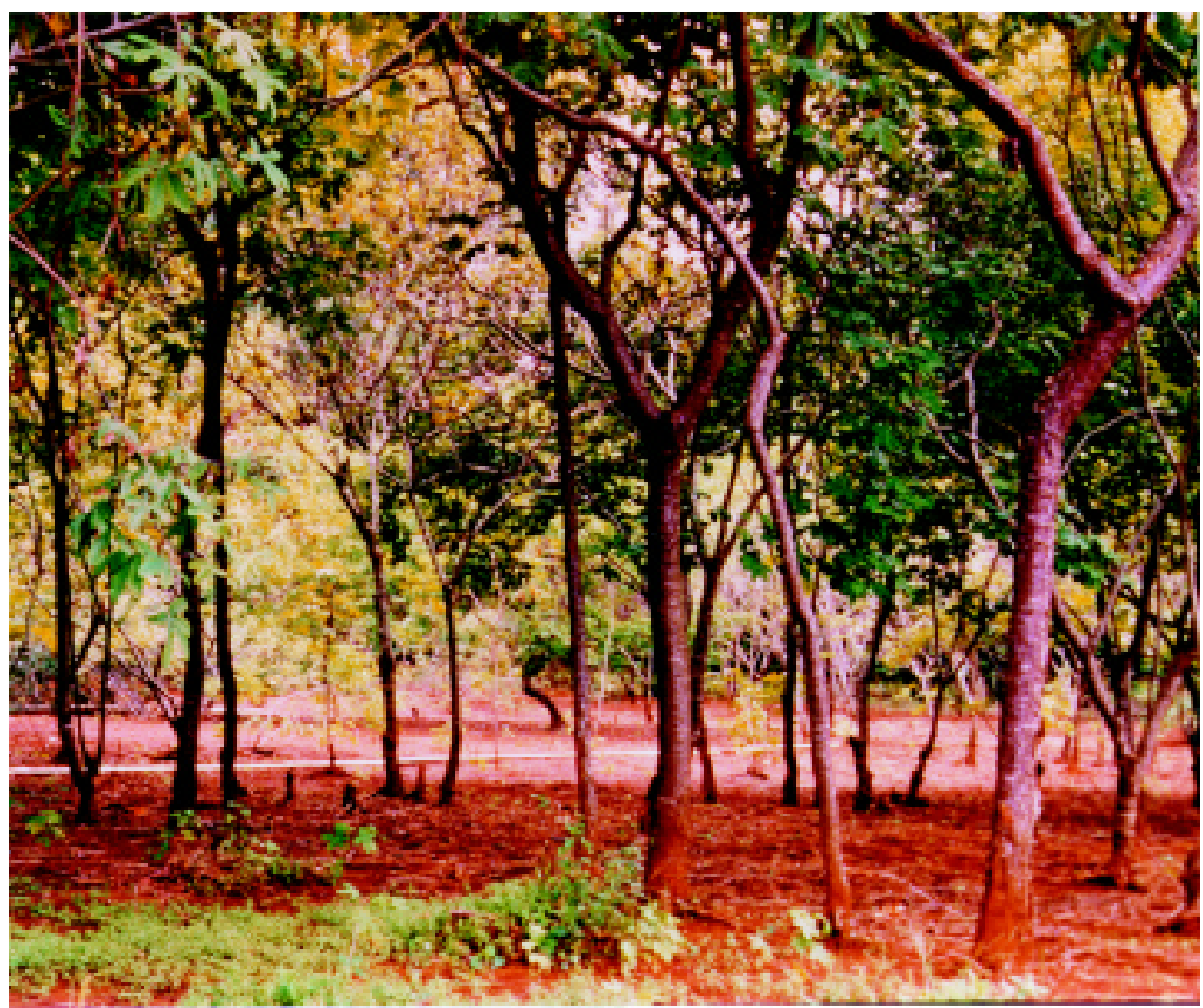

Figure 1 - Wild cassava in the living collection at the Universidade de Brasília.

species were made according to Rogers and Appand (1973) and Nassar (1978a). Natural habitats were described, and 30 accessions of each species were examined for the following characterization: 1) tuber formation and their protein and hydrocyanic acid (HCN) content: tubers were taken 1 year after planting and analyzed according to the Association of Official Analytic Chemists (AOCAC) methods (1970). 2) Adaptation to various soil types: chemical analysis of soil types was carried out according to AOCAC. 3) Adaptation to various habitats was obtained from records of the Federal Meteorological Stations. 4) Seeds, cuttings or whole plants of the collected species were planted in a living collection at the Universidade de Brasília, Brasília.

The collected wild Manihot species were screened rapidly for tuber formation and growth habit. Results of this screening are given in Table IV. Here is the explanation of the table contents:

\section{Tuber formation pattern and protein content}

Among the wild species collected from the State of Goiás, Brazil, four species forming abundant tubers $(M$. oligantha Pax emend. Nassar subsp. nestili, collected from Cristalina; M. tripartita Muell., collected from Serra Dourada, municipality of Goiânia; M. zehntneri Ule, collected from Goianésia, and M. anomala Pohl, collected from Goiânia-Inhumas road). These species were screened for tuber formation pattern, fiber and protein content.

These species differed greatly in tuber formation pattern and tuber composition. M. oligantha subsp. nestili forms abundant cylindrical tubers superficially $(10-30 \mathrm{~cm}$ below soil surface). They are dark brown with a rough surface. M. tripartita forms spherical tubers, deep in the ground below $50 \mathrm{~cm}$. They are bright brown and smooth, with a creamy cortex. $M$. anomala forms oval shaped with a rough surface and light brown color with a creamy cortex superficial tubers at a depth of about $20-30 \mathrm{~cm}$. M. zehntneri forms cylindrical to oval dark brown tubers with a rough surface and a white cortex at a depth of about $50-70 \mathrm{~cm}$. Protein and fiber contents are shown on Table V. The composition of cassava as reported in the literature is somewhat variable. This variation derives from the fact that bitter cultivars differ from sweet ones, not only in the amount of $\mathrm{HCN}$ they contain, but also in the proportions of nutrients. According to Bolhuis (1953), cultivars with roots containing less than $50 \mathrm{mg}$ of $\mathrm{HCN}$ per $\mathrm{kg}$ are considered sweet. However, many reports state that crude protein content ranges from $2.2 \mathrm{mg} / \mathrm{kg}$ in sweet to $2.7 \mathrm{mg} / \mathrm{kg}$ in bitter cultivars and fiber ranges from 3.1 to $10.3 \%$ (Anonymous, 1968). Notably high percentages of protein occur in wild species in comparison to cultivated cassava. Some reports have referred to a protein percentage as high as 5 or $7 \%$ in some cassava cultivars (Anonymous, 1968). Since this estimation of pro- 
Table IV - Tuber formation, growth habit, and other particular characteristics of the wild Manihot species collected.

\begin{tabular}{|c|c|c|c|}
\hline Species & Tuber formation & Growth habit & Particular characteristics \\
\hline M. oligantha Pax subsp. & + & Subshrub & Abundant cylindric tubers \\
\hline M. tripartita Muell. Arg. & + & Subshrub & Abundant spheric tubers \\
\hline M. anomala Pohl & + & Tall shrub & Abundant spheric tubers with strong HCN smell \\
\hline M. zehntneri Ule & + & Tall shrub & Abundant conic tubers \\
\hline M. gracilis Pohl & + & Subshrub & Rare tubers, grows widely all over Central Brazil \\
\hline M. paviaefolia Pohl & + & Subshrub & Rare tubers, occurs in poor sandy soil \\
\hline M. pruinosa Pohl & + & Subshrub & Grows in limestone soil \\
\hline M. falcata Roger \& Appan & - & Subshrub & Grows on slopes and well-drained soil \\
\hline M. reptans $\mathrm{Pax}$ & - & Shrub & $\begin{array}{l}\text { Adapted to large range of soil; exhibits different leaf } \\
\text { shapes; hybridizes easily with other Manihot species } \\
\text { occurring in its natural habitat }\end{array}$ \\
\hline M. alutacea Roger \& Appan & - & Subshrub & Grows on rocky slopes at ca. 1,200 m altitude \\
\hline M. pentaphylla Pohl & - & Subshrub & Grows in limestone soil \\
\hline M. caerulescens Pohl & - & Tall shrub & Adapted to dry areas of northeastern Brazil \\
\hline M. procumbens Muell. Arg. & - & Subshrub & Grow in poor soil, with high concentration of aluminium \\
\hline M. stipularis $\mathrm{Pax}$ & - & Subshrub & Adapted to high altitude, 1,450 $\mathrm{m}$ approximately \\
\hline
\end{tabular}

tein was based on total nitrogen, it must be viewed with caution, because it is not certain whether the breakdown products of cyanogenic glucosides enhance the total nitrogen content or not. Narty (1969) showed that the hydrolytic products of glucosides are incorporated into amino acids for protein synthesis in cassava. It is therefore not unlikely that the reported cultivars with high nitrogen content were simply bitter cultivars with a high glucoside content. One wild species attracting attention is $M$. oligantha subsp. nestili, due to its high protein combined with a very low level of HCN (Nassar, 1978b). The author saw cows and horses eat greedily the vegetative parts and tubers of this species when grazing in their natural habitat. In the literature, two other wild Manihot species have been reported to have high protein content: M. melanobasis (Jennings, 1959) and M. saxicola (Lanjouw, 1939), but as there is no reference to their HCN content, it is not possible to say to what extent crude protein estimates were affected by hydrolytic products of glucosides. It seems logical to find wild cassava with a high protein content, since selection for cultivation has aimed at increased tuber size and decreased fiber content without paying attention on protein content. This could have led to discarding protein-producing genes from the cultivated varieties.

\section{Hydrocyanic acid content}

Tubers of the five species, namely $M$. tripartita, $M$. anomala, M. zehntneri, M. oligantha subsp. nestili, which form abundant tubers, and $M$. gracilis, which grows widely in Central Brazil, were analyzed for HCN content (Table VI). $\mathrm{HCN}$ in fresh unpeeled tubers fell within a range of $238 \mathrm{mg} / \mathrm{kg}$ in M. tripartita to $62 \mathrm{mg} / \mathrm{kg}$ in M. oligantha subsp. nestili. On a dry matter basis, the results were similar, except that $M$. anomala had the highest $\mathrm{HCN}$ content. $\mathrm{HCN}$ content in cassava tubers is reported to vary between cultivars.
Table V - Average protein and fiber content of wild Manihot species on a percent dry matter basis.

\begin{tabular}{|lcc|}
\hline Species & Crude protein (\%) & Crude fiber (\%) \\
\hline M. oligantha Pax & & \\
$\quad$ subsp. nestili & $7.10 \pm 0.58$ & $26.67 \pm 4.86$ \\
M. tripartita Muell. Arg. & $6.88 \pm 1.48$ & $33.48 \pm 6.36$ \\
M. anomala Pohl & $3.74 \pm 0.63$ & $23.44 \pm 4.82$ \\
M. zehntneri Ule & $3.06 \pm 0.82$ & $21.52 \pm 4.82$ \\
\hline
\end{tabular}

Four replicates of 20 tubers of each species were analyzed.

Table VI - Hydrocyanic acid content of unpeeled tubers of wild Manihot species.

\begin{tabular}{|lcc|}
\hline Species & $\begin{array}{c}\text { HCN content in } \\
\text { fresh root }(\mathrm{mg} / \mathrm{kg})\end{array}$ & $\begin{array}{c}\mathrm{HCN} \text { content on dry } \\
\text { matter basis }(\mathrm{mg} / \mathrm{kg})\end{array}$ \\
\hline M. tripartita Muell Arg. & $281.1 \mathrm{a}$ & $357.2 \mathrm{~b}$ \\
M. anomala Pohl & $192.2 \mathrm{a}$ & $1,026.3 \mathrm{a}$ \\
M. zehntneri $\mathrm{Ule}$ & $125.8 \mathrm{~b}$ & $504.2 \mathrm{~b}$ \\
M. gracilis Pohl & $97.2 \mathrm{c}$ & $291.2 \mathrm{c}$ \\
M. oligantha Pax emend. & & \\
Nassar subsp. nestili & $62.3 \mathrm{~d}$ & $183.2 \mathrm{~d}$ \\
\hline
\end{tabular}

Means within a column followed by the same letter are not significantly different by Duncan's multiple range test $(\mathrm{P}=0.05)$.

Analysis of about 100 cultivars for $\mathrm{HCN}$ content by Raymond et al. (1941) gave an average of $158 \mathrm{mg} / \mathrm{kg}$ fresh whole tuber with a maximum value of $438 \mathrm{mg} / \mathrm{kg}$. Little information is available on $\mathrm{HCN}$ content in roots of wild Manihot species; Bolhuis (1953) reported $430 \mathrm{mg} / \mathrm{kg}$ $\mathrm{HCN}$ in fresh roots of $M$. saxicola, but this is probably the only wild Manihot species in which $\mathrm{HCN}$ content has been estimated. He considered that the high $\mathrm{HCN}$ content represented an obstacle to the use of this species in breeding cassava, despite its high protein content, and stated 
that the minimum lethal dose of hydrocyanic acid for a human being is $50-60 \mathrm{mg}$. However, chronic toxicity due to the continuous intake of small amounts of $\mathrm{HCN}$ is considered more important than acute toxicity because of its associaton with many diseases (Oke, 1973).

The occurrence of species with low HCN level is a valuable discovery. The species $M$. oligantha Pax emend. Nassar subsp. nestili, with its notably low HCN content, can be considered a useful parent plant.

\section{Growth habit and natural habitats}

Results of screening wild Manihot species for growth habit and natural habitats are presented in Table IV. Of particular interest is M. paviaefolia which forms tubers, has limited vegetative growth and is adapted to very poor soil. As a parent in cassava breeding programs, it offers potential for additional adaptation to poor soil conditions.

$M$. reptans readily forms hybrids with other species in its natural habitat, producing intermediate forms. Collections made by Ule in 1892 were restricted to the Northern border of Minas Gerais, close to Goiás (Rogers and Appan, 1973), but the author has now found it widespread over most of Goiás. In the last 80 years this species may have expanded its geographical distribution and ecological range through genetic variation and interspecific hybridization. In our samples of $M$. reptans, leaf shape was found to vary widely, reflecting the extent of hybridization with other Manihot species. For example, M. reptans from Goiás Velho was distinguished by bright red leaf veins, a characteristic of the native $M$. alutacea. $M$. reptans was identified by its characteristic growth habit, flower and inflorescence morphology.

Donations of genes from different species adapted to different environments could allow this species to expand rapidly over the whole State of Goiás.

Harlan (1961) gave an example of Helianthus annuis (the annual sunflower) which has acquired a vast gene pool due to the formation of hybrids with at least six other Helianthus species.

M. pruinosa forms tubers with about $3.8 \%$ protein by dry weight, compared to cassava with $2 \%$. As seen in Table IV, M. pruinosa and M. pentaphylla may represent a source of adaptation to limestone soils. The adaptation to high altitude of M. alutacea makes it a good candidate for breeding programs concerned with producing cultivars tolerant to low temperature. $M$. falcata may provide the potential for breeding cultivars with limited vegetative growth which are adapted to well-drained soil.

\section{Adaptation to climatic conditions}

Study of annual rainfall, evaporation and temperature ranges in natural habitats of wild cassavas showed some species to be of particular interest. M. caerulescens Pohl collected from Araripina, State of Pernambuco, and from
Posse, State of Goiás: has shrubs 1-3 m tall, with a deeply extended root to $2 \mathrm{~m}$ underground. They rarely form tubers; tubers were intermittent, at depths exceeding $50 \mathrm{~cm}$; external color was brown, surface smooth and cortex white. Protein content was $3.9 \%$ on a dry matter basis and HCN content was $125 \mathrm{mg} / \mathrm{kg}$ unpeeled fresh root. Chemical analysis of soil showed it to be very poor (Table VII).

A fascinating aspect of the ecology of $M$. caerulescens is its habitat in the western part of Pernambuco and southern Caerá, which are among the most semi-arid regions of the world tropics. The mean average rainfall of this region is about $500 \mathrm{~mm}$, with a high evaporation capacity and high temperature. This unfavorable climate, coupled with poor soil, suggests that this species is capable of affording a potential source of resistance to drought.

Is seems likely that adaptation of M. caerulescens to this arid region depends on its deeply growing root system. However, this species has some distinct characters distinguishing it from other Manihot species. For example, it has very large ribbed fruit, 4-6 times the normal size of Manihot fruits. The author was informed by local inhabitants that seeds are eaten in times of famine. It has a wide range growth extending from Northeastern to Central Brazil. Some biotypes of this species have apparently spread through this area. They tolerate a wide range of environmental conditions varying from severe drought in the regions of Araripina, Picos and Crato, in Pernambuco, Piaui and Ceará States, respectively, to a considerable amount of moisture at Posse in Goiás State (Table VIII).

M. stipularis Pax collected in Brasília is a very short subshrub, ca. $20 \mathrm{~cm}$ tall, which does not form tubers, has a woody root and grows on rocky bancks whose analysis indicates to be a poor soil (Table VII). This species is characterized by dioecious flowers which, together with its very short height, distinguishes it from other Manihot species. M. stipularis was collected from an altitude of about $1,450 \mathrm{~m}$, in one of the highest regions of Brazil. This species may offer genes for adaptations to coolness.

M. procumbens Muell. Arg. collected in Corumbá is a procumbent subshrub (ca. $40 \mathrm{~cm}$ high) with a large woody root and yellow latex, found to grow in a very poor soil. It shows potentiality for tolerance to soil aluminum toxicity and absence of major elements.

Table VII - Analysis of soil from natural habitats of six Manihot spp.

\begin{tabular}{|lccccc|}
\hline Species & $\mathrm{pH}$ & $\begin{array}{c}\mathrm{Ca}^{2+}+\mathrm{Mg}^{2+} \\
(\mathrm{meq} / \mathrm{kg})\end{array}$ & $\begin{array}{c}\text { Phosphorus } \\
(\mathrm{ppm})\end{array}$ & $\begin{array}{c}\mathrm{K}^{+} \\
(\mathrm{ppm})\end{array}$ & $\begin{array}{c}\mathrm{A} 1^{3+} \\
(\mathrm{meq} / \mathrm{kg})\end{array}$ \\
\hline $\begin{array}{l}\text { M. paviaefolia } \\
\text { M. pruinosa } \text { and }\end{array}$ & 4.9 & 2 & - & 16 & 4 \\
$\begin{array}{l}\text { M. pentaphylla } \\
\text { M. caerulescens }\end{array}$ & 5.5 & 191 & 1 & 136 & - \\
$\begin{array}{l}\text { M. procumbens } \\
\text { M. stipularis }\end{array}$ & 5.9 & 1 & 1 & 9 & 2 \\
& 5.0 & 3 & 0 & 18 & 5 \\
\hline
\end{tabular}


Table VIII - Mean monthly precipitation, evaporation and temperature in natural habitats of $M$. caerulescens.

\begin{tabular}{|c|c|c|c|c|c|c|}
\hline \multirow[t]{2}{*}{ Month } & \multicolumn{2}{|c|}{$\begin{array}{l}\text { Precipitation } \\
\text { (mm) }\end{array}$} & \multicolumn{2}{|c|}{$\begin{array}{c}\text { Evaporation } \\
\text { potential }(\mathrm{mm})\end{array}$} & \multicolumn{2}{|c|}{$\begin{array}{c}\text { Temperature } \\
\left({ }^{\circ} \mathrm{C}\right)\end{array}$} \\
\hline & Picos & Posse & Picos & Posse & Picos & Posse \\
\hline Jan & 98.8 & 286.2 & 149.1 & 129.0 & 26.3 & 22.5 \\
\hline $\mathrm{Feb}$ & 168.3 & 89.4 & 138.4 & 129.3 & 25.9 & 22.2 \\
\hline Mar & 130.3 & 68.5 & 124.8 & 264.9 & 25.5 & 25.3 \\
\hline Apr & 31.4 & 117.5 & 120.1 & 167.9 & 25.4 & 23.5 \\
\hline May & 12.6 & 16.4 & 122.4 & 224.3 & 24.5 & 22.5 \\
\hline Jun & 4.1 & 17.6 & 121.9 & 230.9 & 24.3 & 22.0 \\
\hline Jul & 1.1 & 0.7 & 121.2 & 364.1 & 24.1 & 21.9 \\
\hline Aug & 1.3 & 20.2 & 137.7 & 352.3 & 26.4 & 22.8 \\
\hline Sep & 3.2 & 26.3 & 147.0 & 269.1 & 27.8 & 24.5 \\
\hline Oct & 17.9 & 195.2 & 160.6 & 202.4 & 26.1 & 24.1 \\
\hline Nov & 32.2 & 204.3 & 150.3 & 135.6 & 26.0 & 23.9 \\
\hline Dec & 61.7 & 344.1 & 145.8 & 128.0 & 26.2 & 24.9 \\
\hline Total & 556.7 & 1386.4 & & & & \\
\hline
\end{tabular}

The fact that wild Manihot species hybridize easily because of their weak interspecific barriers (Nassar, 1984) must have contributed to the vast variation within this group and the evolution of the large number of species of the genus Manihot.

The use of wild Manihot species for broadening cassava genetic base

Cassava cultivars are deficient in many economically important characters such as resistance to insects, diseases, and drought, and have low protein content (Nassar and Dorea, 1982; Nassar and Grattapaglia, 1986). This can be attributed to the mode of evolution of the species and modifications of the allogamy system of the plant (Nassar and O'Hair, 1985). Lost genes can be restored to the gene pool of the cultigen by interspecific hybridization with wild relatives which possess these genes (Nassar et al., 1986). Wild species of cultivated crops have been frequently used as an important source of genetic diversity and have been employed effectively in a variety of breeding programs. Controlled introgression of genes could alleviate stress problems in cassava in view of the availability of wild relatives which exhibit diversity in adaptation and attributes (Nassar, 1985). There are interspecific barriers to hybridization (Nassar et al., 1986), but these can be broken by the use of a diversity of pollinator gametes.

Nassar, 1989, reported production of interspecific hybrids of two Manihot species, namely $M$. neusana Nassar and $M$. anomala Pax, with cassava by controlled crosses by vector insects. Two wild Manihot species, $M$. anomala and M. neusana, maintained in the living collection at the Experimental Biology Station, Universidade de Brasília, were used in these experiments. Each species was planted in three rows alternating with cassava in October 1983.

In June 1983, 200 seeds were collected from each species and replanted in October 1984 for identification of the occurrence of possible natural hybridization. The following marker genes were used to identify interspecific hybrids: variegated color of fruit dominant to green smooth, red color of flower disk dominant to yellow, setaceous bracteole dominant to foliaceous, and noded stem dominant to smooth. Observations of growth habit, height, stem texture, and tuber formation were also recorded.

In addition to the open pollination for the above mentioned species, 400 manual crosses with pollen of cassava cultivar Catelo were performed.

Of the 200 seeds of $M$. neusana, only 43 seedlings emerged, two hybrids of which were identified. Interspecific hybrids were identified by dominant markers from cassava: noded stem, setaceous bracteoles, ribbed fruit, and tuberculated root (Table IX). Other characters provided indirect evidence of hybridization.

The 200 seeds collected from M. anomala gave rise to 112 seedlinsg. Of these, three showed characteristics of interspecific hybridization. Only one seedling survived to maturity. This hybrid plant exhibited dominant phenotypes from cassava, namely ribbed fruit, red color of the flower disk, noded stem, and tuberous roots (Table X).

These results show that glabrous stem, setaceous foliaceous bracteoles, red-creamy color of flower disks, variegated-green color of fruit, and ribbed-nonribbed fruit are simple marker genes that can be used to recognize interspecific hybridization. It is evident that interspecific barriers between Manihot species can be broken by the use of an abundant diversity of pollinator gametes transmitted by insect vectors. Interspecific crosses were difficult to fertilize manually in this experiment and previous ones

Table IX - Comparison of morphological character for M. neusana, cassava and their hybrid.

\begin{tabular}{|llll|}
\hline Character & M. neusana & Cassava & Hybrid \\
\hline Growth habit & Procumbent shrub & Erect shrub & Erect shrub \\
& $1.5-2 \mathrm{~m}$ & $1.5-2 \mathrm{~m}$ & $1.5-2 \mathrm{~m}$ \\
Young stem texture & Hairy & Glabrous & Hairy \\
Bracteoles & Foliaceous & Setaceous & Setaceous \\
Fruits & Globose, without ribs, & Ovoid, ribbed, green & Ovoid, ribbed, variegated \\
Tuber formation & variegated & Forms tubers & Forms tubers \\
\hline
\end{tabular}


Table X - Comparison of morphological characters for M. anomala. cassava and their hybrid.

\begin{tabular}{|llll|}
\hline Character & M. anomala & Cassava & Hybrid \\
\hline Growth habit & Erect shrub & Erect shrub & Erect shrub \\
& $2-2.5 \mathrm{~m}$ & $1.5-2 \mathrm{~m}$ & $1.5-2 \mathrm{~m}$ \\
Young stem texture & Hairy & Glabrous & Hairy \\
Bracteoles & Semi-foliaceous & Setaceous & Setaceous \\
Flower disk color & Creamy & Red & Red \\
Leaf form & Anomala & Lobed; 5 lobes & Anomala \\
Fruit & Globose, without ribs & Ovoid, ribbed & Ovoid, ribbed \\
Tuber formation & Scarcely forms tubers & Forms tubers & Forms tubers \\
& & & \\
\hline
\end{tabular}

(Nassar et al., 1986). This evidence suggests that barriers between cassava and other Manihot species are weak and evolved recently. It seems that they have arisen not as a primary isolating event, but secondarily after geographic isolation. Nassar (1978a) postulated cassava itself to be an interspecific hybrid that appeared by domestication some 2000 years ago or less.

\section{DEVELOPMENT OF CASSAVA $\times$ WILD SPECIES HYBRIDS}

The wild Manihot species M. neusana was hybridized with the cassava clone Catelo through controlled hybridization with the help of pollinating insects (Nassar, 1989). An interspecific hybrid that combined marker genes of both parents was obtained. The marker genes were ribbed fruit, acquired from cassava, and variegated fruit color from M. neusana. This hybrid (HN) was backcrossed with cassava and used as a pollinator in one, and as a fruit carrier in a second trial.

Virtually the only other report on this subjects is that of Magoon et al. (1966) in which chromosome pairing in the interspecific hybrid of M. glaziovii (rubber tree) and cassava was studied, and a regular chromosome synapsis led them to conclude that there is a strong relationship between this species and cassava. Nassar et al. (1986) suggested that the material used by Magoon was not a pure M. glaziovii, but rather a natural interspecific hybrid between this species and cassava. If this is true, the supposed interspecific hybrid would be a backcrossed progeny. The study of hybrid cassava- $M$. neusana anaphase I by Nassar et al. (1995) showed that out of 40 PMCs studied, 38 cells exhibited laggards, which were attributed to the occurrence of univalents resulting from non-homologous chromosomes.

Analysis of anaphase II showed meiotic restitution. Of 33 PMCs studied in this phase, five cells exhibited a second meiotic restitution (SMR), forming 36 chromosomes on each pole. Apparently this phenomenon is a consequence of meiotic disturbance in the hybrid. An example of this disturbance was the breakdown of anaphase I. Probably this was due to disharmony between the two different genomes. Nassar (1992) previously documented this phenomenon in the interspecific hybrids of cassava with $M$. pseudoglaziovii. The presence of such restitution was confirmed in the following tetrade stage, where the formation of both dyads and tetrads was observed.

Hahn et al. (1990) produced a hybrid between cassava and M. glaziovii. They reported $2 \mathrm{n}$ pollen formation in wild species, in addition to certain clones of cassava itself. The detection of this phenomenon enabled these researchers to isolate triploid and tetraploid types from progeny that came from crosses of cassava with wild Manihot species, namely M. glaziovii and M. epruinosa.

These types proved to be much more productive than commercial clones used in Nigeria. Nassar (1992) manipulated the meiotic restitution occurring in interspecific hybrids of M. pseudoglaziovii with cassava (Figure 2) to produce triploid types that showed very good productivity under semi-arid conditions. The discovery of the frequent occurrence of this phenomenon in interspecific hybrids of cassava offers an effective tool for the production of polyploid types by sexual means, instead of the traditional method of colchicine applied to vegetative parts, which normally induces unstable, chimeral types (Abraham, 1975). An additional advantage is that production of triploid types may lead to the production of trisomics among their progeny. If genes which control productivity in cassava are polygenes with additive model action, as it is the case for many crops, certain trissomics of this crop may be more productive than their diploid ancestors. In general, the production of polyploidy via sexual means is advantageous both from genetic and evolution viewpoints, as it offers a vigorous heterotic effect and releases useful genetic variability adaptations.

Nassar et al. (1995) studied tetrads of cassava interspecific hybrid. They observed 1065 PMC. Of these, 62 cells formed dyads, and 62 cells formed micronuclei. The presence of dyads and triads at this stage confirms what was observed earlier in the anaphase: the occurrence of first and second division meiotic restitution (FMR, SMR).

Both these types are capable of producing $2 \mathrm{n}$ gametes. However, the FMR is more valuable since it pre- 


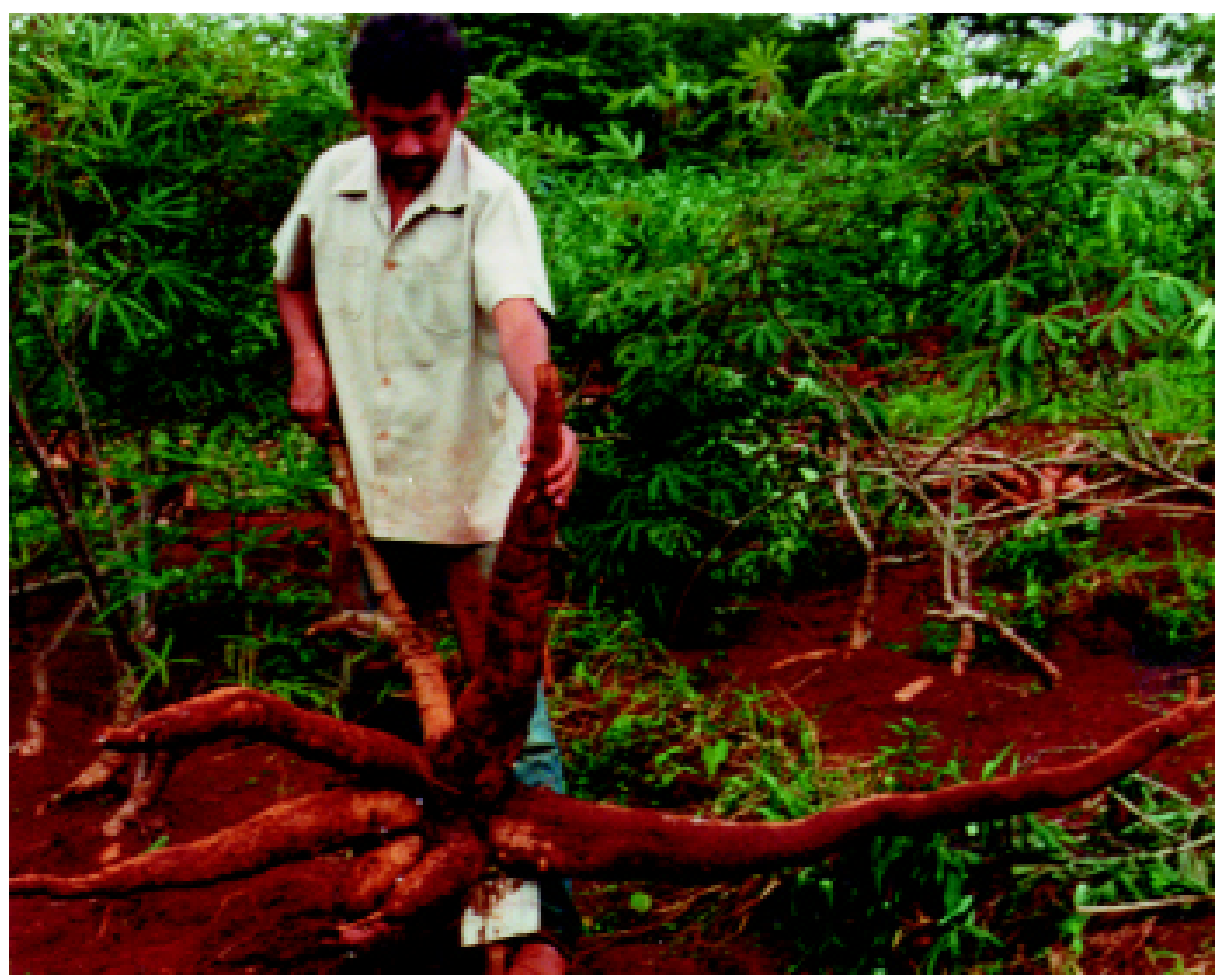

Figure 2 - Interspecific hybrid of Cassava with M. pseudoglaziovii.

serves the major part of its heterosis and epistatic interaction (Mendiburu and Peloquin, 1977; Vorsa and Bingham, 1979).

\section{SIGNIFICANCE OF CASSAVA $\times$ M. NEUSANA HYBRIDS FOR PLANT BREEDING}

The fertility of the hybrid shows the possibility of its further manipulation through backcrosses to transfer useful genes of $M$. neusana to cassava. The backcrossed generations produced were aneuploid $2 n+1+1$ in both cases studied (H01 and H04). In the case of hybrid H04, the plant was completely sterile, having a chromosomal constitution of $2 n+1+1$. Obviously, this hybrid resulted from fertilization of a pollen gamete $n+1+1$ of the parent hybrid (HN), with a cassava ovule of " $n$ ". On the other hand, when the interspecific hybrid HN was used as the maternal plant, a fertile progeny was obtained. When it was used as pollen parent in the backcross with cassava, this resulted in the production of a sterile progeny ( $\mathrm{H04}$ ). Probably this was due to the elimination of fertile embryo genotypes in the progeny because of incompatibility or disharmony between them and the endosperm.

It was concluded that the cassava hybrid with $M$. neusana showed irregular meiotic behavior by lack of complete chromosome pairing, formation of univalents in metaphase I, chromosome retardation in anaphase I, micronuclei in the tetrad, meiotic restitution and reduced pollen viability. When backcrossed to cassava, this inter- specific hybrid produced two aneuploids $2 n+1+1$. These showed irregular meiosis, partial chromosome pairing and the presence of meiotic restitution.

The most important observation was the obtainment of high set fruit from one of the $2 n+1+1$ backcrossed hybrid. This revealed in future study to be due to apomixis. Clearly this gene was transferred from M. neusana to cassava. This discovery opens the door to one of the most important achievements in cassava breeding, namely the production of bacterial diseases-free clone through apomixis, maintaining in the same time superiority of paternal genotypes without suffering any segregation breakdown.

\section{ACKNOWLEDGMENTS}

This work is partially supported by the Conselho Nacional de Desenvolvimento Científico e Tecnológico (CNPq), Brasília. The above mentioned living collection of wild Manihot species was established at the Universidade de Brasília with the assistance of the International Development Research Center (IDRC), Ottawa.

\section{RESUMO}

Espécies selvagens de Manihot dão origem à mandioca. Elas constituem valioso reservatório genético, com genes mostrando novos caracteres. O exame cuidadoso dessas espécies mostrou que algumas delas têm uma percentagem notavelmente alta de proteína combinada com uma porcentagem baixa de ácido cianídrico. $\mathrm{O}$ estudo dos habitats naturais revelou resistência à 
seca e à toxicidade por alumínio em excesso no solo, assim como adaptação a baixas temperaturas. Alguns dos híbridos obtidos mostraram alta produtividade da raiz e resistência a brocas do caule. A apomixia foi descoberta nas espécies selvagens e transferida com sucesso para as espécies cultivadas.

\section{REFERENCES}

Abraham, A. (1975). Breeding of tuber crops in India. J. Genet. Plant Breed. 17:212-217

Allem, A.C. (1994). The origin of Manihot esculenta Crantz. Genet. Resour. Crop Evol. 41: 133-150.

Anonymous (1968). Tabla de Composicion de Pastes e otros Alimentos de Centro America. Publicacion No. E-440. Instituto Nacional de Centro America e Panama, Panama.

Bolhuis, G.G. (1953). A survey of some attempts to breed cassava varieties with a high content of proteins in the roots. Euphytica 20: 107112 .

Cruz, N.D. (1968). Citologia no gênero Manihot Adans. 1. Determinação do número de cromossomo em algumas espécies. An. Acad. Bras. Cienc. 40: 81-95.

Dobzhansky, T. (1973). Genética do Processo Evolutivo. Tradução de Celso Abbade Mourão. Polygono, São Paulo, Brazil.

Gattapaglia, D. and Sederoff, R.R. (1994). Genetic linkage maps of Eucalyptus grandis and E. uroplylla using a pseudo-testcross strategy and RAPD markers. Genetics 137: 1121-1137.

Grattapaglia, D.E., Nassar, N.M.A. and Dianese, J. (1986). Biossistemática de espécies brasileiras do Gênero Manihot baseada em padrões de proteína da semente. Cienc. Cult. 39: 294-300.

Hahn, S.K., Bai, K.V. and Asiedu, R. (1990). Tetraploids, triploids and 2n pollen from diploid interspecific crosses with cassava. Theor. Appl. Genet. 79: 433-439.

Harlan, J. (1961). Geographic origin of plants useful to agriculture. In: Germplasm Resources. Publ. Am. Assoc. Adv. Sci. 66: 3-9.

Hayson, H.R., Chan, T.L. and Hughs, M. (1994). Phylogenetic relationships of Manihot species revealed by restriction fragment length polymorphism. Euphytica 76: 227-234

Jennings, D.L. (1959). Manihot melanobasis Muell. Arg. - A useful parent for cassava breeding. Euphytica 8: 157-162.

Laemmli, U.K. (1970). Cleavage of structural proteins during assembly of the head of bacteriophage T4. Nature 227: 680-685.

Lanjouw, J. (1939). Two interesting species of Manihot L. from Surinam. Recueil. Trav. Bot. Neerlandais 36: 542-549.

Magoon, M.L., Jos, J.S. and Appan, S.G. (1966). Cytomorphology of interspecific hybrid between cassava and Ceara rubber. Chromosome Infor. Serv. 7: 8-10.

Mendiburu, A.O. and Peloquin, S.J. (1977). The significance of $2 \mathrm{n}$ gametes in potato breeding. Theor. Appl. Genet. 49: 53-61.

Mok, D.W.K. and Peloquin, S.S. (1975). The inheritance of three mechanisms of diploandroid ( $2 \mathrm{n}$ pollen) formation in diploid potatoes. $\mathrm{He}$ redity 35: 295-302.

Narty, F. (1969). Studies on cassava, Manihot utilissima Pohl. 1. Cyanogenesis: the biosynthesis of linamarin and lutaustalin in etioled seedlings. Phytochemistry 7: 1307-1312.

Nassar, N.M.A. (1978a). Conservation of the genetic resources of cassava (Manihot esculenta). Determination of wild species localities with emphasis on probable origin. Econ. Bot. 32: 311-320.

Nassar, N.M.A. (1978b). Microcenters of wild cassava, Manihot spp., diversity in Central Brazil. Turrialba 28: 345-347.

Nassar, N.M.A. (1978c). Some further species of Manihot with potential value to cassava breeding. Can. J. Plant Sci. 58: 915-916.

Nassar, N.M.A. (1978d). Wild Manihot species of Central Brazil for cassava breeding. Can. J. Plant Sci. 58: 257-261.

Nassar, N.M.A. (1979a). A study of the collection and maintenance of the germplasm of wild cassava, Manihot spp. Turrialba 29: 221-224.

Nassar, N.M.A. (1979b). Three wild Manihot species of Central Brazil with tolerance to stress conditions. Can. J. Plant Sci. 59: 553-555

Nassar, N.M.A. (1980a). Attempts to hybridize wild Manihot species with cassava. Econ. Bot. 34: 13-15.

Nassar, N.M.A. (1980b). The need for germplasm conservation in wild cassava. Indian J. Genet. Plant Breed. 39: 465-470.

Nassar, N.M.A. (1982). Collecting wild cassava in Brazil. Indian J. Genet. 42: 405-411.

Nassar, N.M.A. (1984). Natural hybrids between Manihot reptans Pax and M. alutacea Rogers \& Appan. Can. J. Plant Sci. 64: 423-425.

Nassar, N.M.A. (1985). Manihot neusana Nassar: A new species native to Paraná, Brazil. Can. J. Plant Sci. 65: 1097-1100.

Nassar, N.M.A. (1986a). Genetic variation of wild Manihot species native to Brazil and its potential for cassava improvement. Field Crops Res. 13: $177-184$

Nassar, N.M.A. (1986b). Collecting wild cassava in Northern Mexico. FAO/ IBPGR Plant Genet. Resour. Newsl. 65: 29-30.

Nassar, N.M.A. (1989). Broadening the genetic base of cassava, Manihot esculenta Crantz by interspecific hybridization. Can. J. Plant Sci. 69: 1071-1073.

Nassar, N.M.A. (1992). Production of triploid cassava, Manihot esculenta Crantz by diploid hybrid gamete. Field Crops Res. 30: 173-182.

Nassar, N.M.A. (1994a). Development and selection of apomixis in cassava, Manihot esculenta Crantz. Can. J. Plant. Sci. 74: 857-858.

Nassar, N.M.A. (1994b). Relationships of Manihot species. Proceedings of the 2nd Symposium of Cassava Biotechnology Network, Bogor, pp. 90-100.

Nassar, N.M.A. and Costa, C.P. (1976). Tuber formation and protein content in some wild cassava species native to Central Brazil. Experientia 33: 1304-1305

Nassar, N.M.A. and Dorea, G. (1982). Protein content in some cassava cultivars and its hybrid with wild Manihot species. Turrialba 32: 429-432.

Nassar, N.M.A. and Fitchner, S. (1978). Hydrocyanic acid content in some wild Manihot (cassava) species. Can. J. Plant Sci. 58: 577-578.

Nassar, N.M.A. and Grattapaglia, D. (1986). Variabilidade de clones de mandioca em relação a fertilidade e aspectos morfológicos. Turrialba 36: 555-559.

Nassar, N.M.A. and O'Hair, S. (1985). Variation among cassava clones in relation to seed germination. Indian J. Genet. Plant Breed. 45: 394-398.

Nassar, N.M.A., Rafael da Silva, J. and Vieira, C. (1986). Hibridação interespecífica entre mandioca e espécies de Manihot. Cienc. Cult. 38: 1050-1055.

Nassar, N.M.A, Vieira, C. and Saraiva, L.S. (1995). Cytogenetic behaviour of interspecific hybrid of Manihot neusana Nassar and cassava, $M$. esculenta Crantz, and its backcross progeny. Can. J. Plant Sci. 75: 675-678.

Nichols, R.F.W. (1947). Breeding cassava for resistance. East Afr. Agr. J. 12: 184-194.

Oke, O.L. (1973). The mode of cyanide detoxification. In: Chronic Cassava Toxicity (Nestel, B. and Maclntyte, R., eds.). Proceedings of the Interdisciplinary Workshop, London, 29-30 January 1973. IDRC-OLOe, Ottawa, Ontario, Canada, pp. 97-104.

Raymond, W.D., Jojo, W. and Zicodemus, Z. (1941). The nutritive value of some tanganyka foods: cassava. East Afr. Agric. J. 6: 154-159.

Rogers, D.J. (1963). Studies on Manihot esculenta Crantz and related species. Bull. Torrey Bot. Club 99: 43-54.

Rogers, D. and Appan, C. (1973). Manihot, Manihotoides, Euphorbiaceae. Flora Neotropica. Hafner Press, New York, NY.

Schmidt, C.B. (1951). A Mandioca. Contribuição para o Conhecimento de sua Origem. Boletim Agric. 1,1, São Paulo.

Stebbins, G.L. (1950). "Variation and Evolution in Plants". Columbia Press, New York.

Vavilov, N.I. (1951). Phytogeographic basis of plant breeding. The origin, variation, immunity and breeding of cultivated plants. Chron. Bot 13: $1-366$.

Vorsa, N. and Bingham, E.T. (1979). Cytology of pollen formation in diploid alfalfa, Medicago sativa. Can. J. Genet. Cytol. 21: 526-530.

Webber, K. and Osborn, M.J. (1969). The reliability of molecular weight determination by sulfatepolyacrylamide gel electrophoresis. J. Biol. Chem. 244: 4406-4412.

(Received January 21, 1999) 